\title{
TRES CANTOS DE AMOR A STALINGRADO DE PABLO NERUDA Y OCHO INTERPRETACIONES EN LA TRADUCCIÓN
}

\author{
PABLO NERUDA'S THREE LOVE SONGS TO STALINGRAD \\ AND THEIR EIGHT INTERPRETATIONS IN TRANSLATION
}

Olga Stanislávovna Chesnokova

Peoples' Friendship University of Russia. Moscú, Rusia tchesnokova_olga@mail.ru

Pedro Leonardo Talavera Ibarra

Universidad Estatal del Sur de Missouri. Missouri, Estados Unidos

talavera-P@mssu.edu

\begin{abstract}
Dablo Neruda (1904-1973) es una figura excepcional en la poesía universal. Es no solamente el autor de una gran cantidad de obras y colecciones de versos, sino asimismo un innovador del lenguaje poético. Dicha originalidad le hizo acreedor al Premio Nobel de Literatura en 1971, pues su poesía revive "los sueños y el destino de un continente con la energía de una fuerza de la naturaleza" (The Official Web Site of the Nobel Prize, 2015).

Precisamente esa fuerza primigenia característica de la personalidad de Neruda encontró expresión en una participación activa y sin compromisos en la vida civil. Durante la Segunda Guerra Mundial, en los años 1942 y 1943, Neruda escribe dos obras extraordinarias por la vehemencia de su impacto emocional: "Canto a Stalingrado", subsecuentemente "Canto de amor a Stalingrado" (Neruda, 1967), y "Nuevo canto de amor a Stalingrado" (Neruda, 1967a). Finalmente, en 1949, Neruda cierra el ciclo con su "Tercer canto de amor a Stalingrado" (Neruda, 1967b). El presente texto examina la creación y la historia de estos poemas, su estética y sus traducciones a la lengua rusa.

En la obra de Neruda los dos primeros cantos de amor a Stalingrado se
\end{abstract}


caracterizan por la resonancia de una nueva voz poética que se remonta al ciclo España en el corazón de 1938. Si en una primera etapa, la de 20 poemas de amor y una canción desesperada (1924), la poesía de Neruda se impregnó de la exaltación erótica de la juventud, y en un segundo período, Residencia en la tierra (1933), de la sombría introspección solitaria; a partir de 1938 su voz era la expresión de un profundo compromiso social y cívico.

El mismo uso de la palabra "canto" se asocia directamente con la experiencia personal al interior de la épica y la historia, con el verso sobre el "valor, los hechos, las proezas" a la manera de La Araucana (Ercilla y Zúñiga, 1776). El sustantivo "canto" en el título de los poemas a Stalingrado se puede interpretar como la singular visión épica e histórica de Neruda, semejante a la que ofreciera en la aurora de la literatura chilena el joven soldado español Alonso de Ercilla y Zúñiga (1533-1594), quien inmortalizó las "temerarias empresas" e "industrias" de la indómita gente de Arauco, hechas memorables para engrandecer la reputación de los vencedores españoles.

Los cantos nerudianos anteriores a Stalingrado estaban ligados a la causa de la España Republicana: "Canto a las madres de los milicianos muertos" y "Canto sobre unas ruinas". Pero sólo después de Stalingrado, sus poemarios se volverán cantos: Canto general de Chile (1943) y Canto general (1950).

Ya en 1937 Neruda había formulado su nuevo arte poética en "Explico algunas cosas” (Объяснение en la traducción al ruso de Ilyá Ehrenburg):

Preguntaréis: y dónde están las lilas?

Y la metafísica cubierta de amapolas? ...

Preguntaréis por qué su poesía no nos habla del sueño, de las hojas, ...?

Venid a ver la sangre por las calles, venid a ver la sangre por las calles (Neruda, 1967d).

Вы спросите: где же сирень, где метафизика, усыпанная маками, где дождь, что выстукивал слова, полные пауз и птиц? Я вам расскажу, что со мною случилось. 


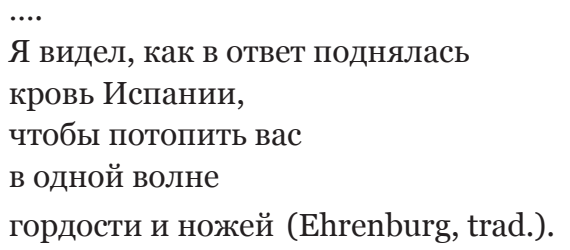

Neruda vive en la Ciudad de México y funge como cónsul de Chile en México a partir de agosto de 1940. Los dos primeros cantos de amor (19421943) se enmarcan cronológicamente en las fechas de la batalla por Stalingrado. La batalla, el mayor enfrentamiento terrestre en la historia de la humanidad, comienza el 23 de agosto de 1942 con un bombardeo aéreo alemán que mata a casi cien mil habitantes, uno de cada cuatro, y convierte la ciudad en ruinas. Termina el 2 de febrero de 1943 con la liberación de la ciudad por las tropas soviéticas, después de más de 150 días de sitio y más de dos millones de muertos por ambas partes. La victoria se convierte en el momento de torsión de la Segunda Guerra Mundial.

"Canto a Stalingrado" fue leído por primera vez en un acto público organizado por la Sociedad de Amigos de la URSS el 29 de septiembre de 1942, apenas un mes después del inicio de las hostilidades. Ese mismo martes por la noche, algunos de los asistentes al Teatro del Sindicato Mexicano de Electricistas pegan en los muros de la Ciudad de México carteles que son la primera edición del poema.

En 1943, al poco tiempo de la victoria del Ejército Rojo, Neruda escribe y publica "Nuevo canto de amor a Stalingrado". Su lectura se lleva a cabo el 29 de enero de 1943 en un banquete en honor de la URSS. Nuevamente la Sociedad de Amigos de la URSS es la encargada de la publicación del texto. $\mathrm{Al}$ ahora Comité de Ayuda a Rusia en Guerra son cedidos los derechos de autor para "el auxilio de los combatientes y las poblaciones civiles de la Unión Soviética" (Neruda, 1943). La primera edición consta de cien ejemplares numerados y firmados por Neruda; y de cinco mil ejemplares más, terminándose su impresión en los Talleres Gráficos de la Nación el 25 de febrero de 1943 (Neruda, 1943).

Pablo Neruda visita la URSS en 1949 en ocasión del 150 aniversario del nacimiento del gran poeta ruso Alexandr Pushkin y viaja por primera vez a la heroica ciudad a orillas del Volga que describió sin haberla conocido. Su lectura de los poemas a Stalingrado es recibida con un enorme entusiasmo; 
y su estancia en la ciudad lo inspira a escribir el "Tercer canto de amor a Stalingrado" (Neruda, 1967b).

El motivo recurrente de "Canto de amor a Stalingrado" se halla en una serie de preguntas a la naturaleza (la tierra, el sol, el alba, "la luz del día que viene"), cuyo propósito es saber si la heroica ciudad podrá sostenerse. El poema comienza con las preguntas de un labriego para pasar a las de un marinero y, más tarde, a las de un español. Después interviene el yo del poeta ("y yo digo...") para transformarse en la voz colectiva del nosotros ("nuestros corazones... no podemos..."). La interrogativa sin respuesta es "si Stalingrado vive". El tono pesimista pero lleno de esperanza del poema a veces suena como un lamento por Stalingrado, otra Numancia que será consumida por las llamas del fuego antes que rendirse: “iAunque mueras, no mueres!”.

Distinguen al Canto de amor a Stalingrado las transiciones en la voz poética y los múltiples símbolos que crean el mensaje poético: la ciudad debe sobrevivir. Cerca del final del texto el poeta se identifica con la voz de toda América Latina. Como es característico para el estilo de Neruda, los símbolos toponímicos (en este caso, los gentilicios) se incorporan de manera orgánica a la estética y al flujo emocional de la obra:
Ciudad, Stalingrado, no podemos
llegar a tus murallas, estamos lejos.
Somos los mexicanos, somos los araucanos, somos los patagones, somos los guaraníes, somos los uruguayos, somos los chilenos, somos millones de hombres (Neruda, 1967).

Las obras de Neruda surgen del sistema silábico-tónico del español, que no es familiar para el lector ruso. Ilyá Ehrenburg, erudito conocedor del estilo de Neruda, advierte que "el encanto de la poesía de Neruda radica en el enlace orgánico de las palabras, las imágenes y los sentimientos, mismos que no necesitan ni la cincha del metro poético ni las campanillas de la rima" (Ehrenburg, en Neruda, 1965). Goncharenko llegó incluso a proponer el título de "verso libre nerudiano" para dicho estilo (Goncharenko, en Neruda, 1976).

"Canto de amor a Stalingrado" se escribió usando precisamente el "verso libre nerudiano" sin rima y en alejandrino, verso de catorce sílabas que exige una cesura, lo que requiere una lectura con pausa al interior de cada 
verso. El poema está permeado por anáforas y las ya mencionadas transiciones de la voz poética: el narrador en la tercera persona; el "yo" del poeta; el imperativo "tú"; y el pronombre de tratamiento "vosotros", que como vocativo en las versiones nacionales del español de América Latina adquiere la connotación de un tono elevado, dando al poema una sonoridad épica.

"Nuevo canto de amor a Stalingrado" está escrito de una manera totalmente diferente, pues es, curiosamente, unos de los poemas más formales de Neruda. Escrito en verso endecasílabo melódico largo, el poema consiste de veintiocho versos con rima consonante en los versos pares, y asonante en los impares. Los versos son una secuencia de cuartetos, cada uno de los cuales culmina con el nombre de la ciudad, Stalingrado.

"Nuevo canto de amor a Stalingrado" empieza con una introspección personal en que el poeta rememora los temas líricos de su obra en el pasado, contrapuestos a Stalingrado:

Yo escribí sobre el tiempo y sobre el agua, describí el luto y su metal morado, yo escribí sobre el cielo y la manzana, ahora escribo sobre Stalingrado (Neruda, 1967a).

La reflexión personal ("Yo escribí"; "Yo toqué"; "Yo sé"; "Yo pongo"; "Mi voz") da lugar a un diálogo entre el poeta y la ciudad ("tú"), subrayado por la repetición del nombre Stalingrado al final de cada estrofa. El diálogo es suspendido solamente para hacer inventario de las acciones de sus enemigos por medio de la anáfora "Los que":

Los que humillaron...

Los que... pasaron pisoteando...

Los que... han escupido...

Los que... quemaron y rompieron...

Los que... salpicaron...

Los que... quemaron...

La voz poética retorna al "yo" del poeta, finalmente, para proclamar su nuevo propósito:

Yo pongo el alma mía donde quiero.

Y no me nutro de papel cansado, 
adobado de tinta y de tintero.

Nací para cantar a Stalingrado (Neruda, 1967a).

Todas estas características hacen del poema un himno a la heroica ciudad. Por esta razón no es de extrañar que "Nuevo canto de amor a Stalingrado" haya pasado a formar parte de los primeros libros de texto en español de las universidades soviéticas después de la guerra (VassílievaShvede, 1948).

Los traductores a la lengua rusa de los cantos de amor personifican el orgullo y el acervo de la poesía, de la filología y del pensamiento humanista rusos. Ellos son:

-Ilyá G. Ehrenburg (1891-1967), prosista, poeta, traductor del francés y español, publicista, fotógrafo, activista social y amigo personal de Pablo Neruda, a quien conoció en 1936 en la España Republicana. Hay un hermoso poema de Neruda, dedicado a su amigo ruso Ilyá Ehrenburg (Neruda, 1967c).

-Fiódor V. Kellin (1893-1965), filólogo hispanista y traductor, autor del primer diccionario español-ruso en la Unión Soviética.

-Evgueniy A. Dolmatovsky (1915-1994), reconocido letrista soviético, autor de gran cantidad de canciones populares interpretadas por los más renombrados cantantes rusos (L. Zykina, A. Mironov, E. Pieja y otros).

-Pável M. Grushkó (1931-), poeta y traductor de poesía y prosa en español.

-Serguéi F. Goncharenko (1945-2006), poeta, traductor, estudioso de la poética en español, autor de más de 150 obras sobre lingüística comparativa y general, teoría de la traducción y comunicación poética.

-Ovadiy G. Sávich (1896-1967), prosista y poeta, traductor de poesía latinoamericana y española y corresponsal de TASS en España de 1937 a 1939 .

En lengua rusa existen tres traducciones del "Canto de amor a Stalingrado" (Ehrenburg, Kellin y Grushkó); cuatro del "Nuevo canto de amor a Stalingrado" (Ehrenburg, Kellin, Dolmatovsky y Goncharenko); y una del "Tercer canto de amor a Stalingrado" (Sávich).

La traducción de cualquier texto literario es por sí misma una faceta 
nueva que se acerca solo relativamente al original. La traducción poética debe tomar en consideración tanto el significado y la estética como el no menos importante elemento del ritmo. Como parte del proceso, en palabras de Goncharenko, "se permite y es común el 'enriquecimiento' de la traducción por medio de omisiones o complementos".

Las siguientes son tres traducciones y el original en "verso libre nerudiano" del principio de "Canto de amor a Stalingrado":

En la noche el labriego duerme, despierta y hunde su mano en las tinieblas preguntando a la aurora: alba, sol de mañana, luz del día que viene, dime si aún las manos más puras de los hombres defienden el castillo del honor, dime, aurora, si el acero en tu frente rompe su poderío, si el hombre está en su sitio, si el trueno está en su sitio.

Ночью крестьянин спит, и он просыпается, Он погружает руки в темноту, он спрашивает Рассвет:

«Заря, солнце утра, свет идущего дня, Скажи мне, все еще самые чистые руки Город гордости держат?

Скажи мне, заря, Все ли железо лицо твое ранит?

И стоит ли еще человек и гремит ли еще гроза?» (Ehrenburg, trad.).

Над миром ночь... Пеон с плантаций спит Тревожным сном...Но вот он пробудился. В окрестный сумрак простирая руки, Он будит в небе алую зарю. «Скажи, заря, - так говорит пеон,И ты скажи мне, солнце золотое, Светило дня, все также ль защищают Бойцы-герои Замок Чистой Славы, Дробя металл о блеск твоих лучей?» (Kellin, trad.).

Пахарь, спавший в ночи, пробудился и тянет руку свою в потёмки - спрашивает зарю: «Зорька, юное солнце, свет спешащего утра, всё ли ещё под силу самым чистым рукам драться за гордый замок славы? Скажи, заря, 
всё ли ещё железо грудь тебе решетит?

А человек - стоит там, где должен стоять?

А молния - не умерла?» (Grushkó, trad.).

Y éste es un ejemplo de la integración de la voz del labriego con la voz del poeta:

dime, dice el labriego, si no escucha la tierra
cómo cae la sangre de los enrojecidos
héroes, en la grandeza de la noche terrestre,
dime si sobre el árbol todavía está el cielo,
dime si aún la pólvora suena en Stalingrado .

Скажи мне, - говорит крестьянин, - земля еще слышит,

Как героев тяжелая падает кровь?

Скажи мне, есть ли еще над деревом небо?

Битва, скажи мне, идет ли еще в Сталинграде? (Ehrenburg, trad.).

Ответьте мне, - так говорит пеон, -

По-прежнему ль скорбящая Земля

Всем сердцем чует, как струится кровь

Бойцов-героев, битвой обагренных,

В кромешной тьме, нависшей над вселенной?

По-прежнему ль в раскатах огневых,

Вставая к небу деревом победным,

С врагами бьется смелый Сталинград? (Kellin, trad.).

Спрашивает у зари

пахарь: «Скажи, заря, разве земля не слышит, как струится во мглу кровь багряных героев в необъятную мглу полуночного простора?

Всё ли ещё небеса опираются на деревья?

Всё ли ещё грохочут взрывы над Сталинградом?»

А молния - не умерла? (Grushkó, trad.).

El contexto toponímico de los símbolos que conforman la voz del continente se ofrece por medio de la traducción de los gentilicios de las distintas regiones y países de América Latina:

Сталинград, мы не можем прийти к твоим стенам, 
Мы далеко, мы не в силах прийти, Мы, мексиканцы, мы, чилийцы, арауканцы, Мы, патагонцы, уругвайцы, гварани. Нас Миллионы (Ehrenburg, trad.).

О город Сталинград! Увы, не можем Мы стен твоих достигнуть... Мы далеко, Мы мексиканцы, мы арауканцы, Мы патагонцы, гварани...мы все Чилийцы, уругвайцы... Нас мильоны! (Kellin, trad.).

Сталинград, мы не можем к стенам твоим пробиться, город, мы далеко!

Мы - это мексиканцы, арауканы, мы патагонцы, гуарани, уругвайцы, чилийцы нас миллионы людей (Grushkó, trad.).

Todas las cuatro traducciones del "Nuevo canto de amor a Stalingrado" se ajustan a la métrica de la versificación rusa tradicional. La traducción de Ehrenburg pone más atención al ritmo y rima del poema, observando su tradicional apego al léxico y anáforas nerudianos. Kellin hace lo propio en su particular estilo. Dolmatovsky, por su parte, reinterpreta el poema, a veces arbitrariamente, para compaginar la voz del poeta con la suya. Ante la aparente imposibilidad de esta compaginación, Goncharenko decide reescribir el poema en ruso, convirtiendo al original en una mera referencia. Cada una de las cuatro versiones en la traducción es una interpretación transformada en una nueva y completa creación poética. Un ejemplo ilustrativo es la estrofa inicial del original y sus traducciones:

Yo escribí sobre el tiempo y sobre el agua, describí el luto y su metal morado, yo escribí sobre el cielo y la manzana, ahora escribo sobre Stalingrado.

Я прежде писал о дожде и море, Описывал небо, плодовый сад, Писал о металле лиловом горя, Теперь о тебе пишу, Сталинград! (Ehrenburg, trad.). 
Я прежде песни пел о ветре и воде,

Металлом траура тревожил ясность взгляда,

Я пел о небесах и о земном плоде -

Теперь я песнь пою величью Сталинграда (Kellin, trad.).

Сочинял я о вечности, небе, озерах, Траур в бронзе описывать больше не надо. Я теперь обращаюсь и словом и взором К Сталинграду - к тебе, Сталинградо! (Dolmatovsky, trad.).

Я говорил о времени и небе, о яблоке, о грусти листопада, о трауре утрат, дожде и хлебе, но эта песнь - о стали

Сталинграда (Goncharenko, trad.).

Cada traducción del primer cuarteto muestra una específica interpretación creativa del texto nerudiano. Cabe destacar en Ehrenburg y Kellin la virtuosidad en trasmitir los símbolos del color. Dolmatovsky recurre a repetir el nombre de la ciudad: la primera vez con el ruso «Сталинград»; y la segunda con la transliteración del español, «Сталинградо». Goncharenko recrea con maestría la resonancia épica gracias a un complemento propio: la cercanía del lexema “сталь (acero)” у el topónimo "Сталинград (ciudad del acero, ya que el seudónimo de Stalin provenía del vocablo ruso сталь "acero")", lo que se encuentra incluso en la traducción de las estrofas finales del poema, mismas que pueden servir de ejemplo para una comparación de estas versiones:

Guárdame un trozo de violenta espuma, guárdame un rifle, guárdame un arado, y que lo pongan en mi sepultura con una espiga roja de tu estado, para que sepan, si hay alguna duda, que he muerto amándote y que me has amado, y si no he combatido en tu cintura dejo en tu honor esta granada oscura, este canto de amor a Stalingrado.

Клок яростной пены, лавы осколок, Винтовку и плуг я свято храню, 
С ними твоей державы красный колос Положите в могилу мою.

Пусть знают все - то верности клятва,хоть не был я средь твоих солдат, Тебя я люблю любовью солдата, Тебе я оставил эту гранату Эта песнь любви тебе, Сталинград! (Ehrenburg, trad.).

Мне пену гневных волн навеки одолжи, Винтовку дай и плуг с осколками снаряда И красный колос свой на гроб мне положи В тот день, когда умру, - в день скорбного обряда.

И скажут все тогда, сомненье истребя:

«Пусть он не защищал священную ограду, Но он любил ее, и умер он любя, И словно острый штык, сковал он для тебя Вот эту песнь любви и славы Сталинграду!» (Kellin, trad.).

Чтобы знали повсюду: я был твоим братом И любил тебя крепкой и верной любовью, И, хотя не сражался я рядом с тобою, В честь тебя поднимаю я, как гранату, Эту песню любви к Сталинграду! (Dolmatovsky, trad.).

И в час, когда навек замрёт мой голос, пускай осколок твоего снаряда положат мне на гроб, а сверху - колос, кровавый колос нивы Сталинграда.

И это будет памятник поэту, которому иных наград не надо: пусть я и не ковал твою победу, но выковал острей клинка вот эту стальную песнь во славу Сталинграда. (Goncharenko, trad.)

El "Tercer canto de amor a Stalingrado", al igual que el "Canto de amor a Stalingrado", está escrito en "verso libre nerudiano" y describe a una 
ciudad pacífica, pero llena de recuerdos de la guerra. A diferencia de los primeros dos, este poema tiene en el título su numeración, Tercer. En la obra Neruda destaca el significado histórico de la lucha por Stalingrado y la hazaña de los estalingradenses:

Aquí se cortó el nudo que apretó la garganta de la historia.

Здесь разрублен был узел, затянутый на шее истории (Sávich).

Sávich con maestría recrea el tratamiento personificado del original ("una rama de acacia,/ hojas, flores, espinas defensoras"; “ветка акации с шипами и цветами”), creando con la inversión del orden de las palabras una sonorización elevada y escrupulosamente transmitiendo el sentido del original. Hay también inevitables reemplazos, como, por ejemplo, la sustitución de "el soldado soviético" en el original por "el hombre soviético":

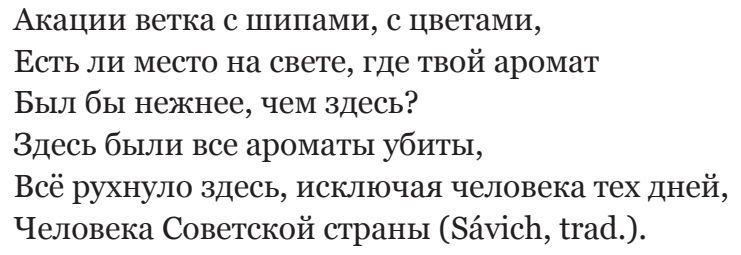

El elevado tratamiento sonoro a la rama de acacia se crea en otro fragmento a partir del complemento en la traducción con la exclamación "Oh" (“O”) y el adjetivo “olorosa “(“благоуханная”):

Aquí hueles a hombres y a esperanza, aquí, rama de acacia, no pudo quemarte el fuego ni sepultarte el viento de la muerte.

О благоуханная ветка, Здесь аромат твой

Сильнее, чем все ароматы весны: ведь он говорит о надежде и человеке (Sávich, trad.). 
Neruda anuncia que Stalingrado ha enseñado al mundo cómo resurgir de las cenizas, haciendo eco al llamado del Canto de amor a Stalingrado, “iAunque mueras, no mueres!”:

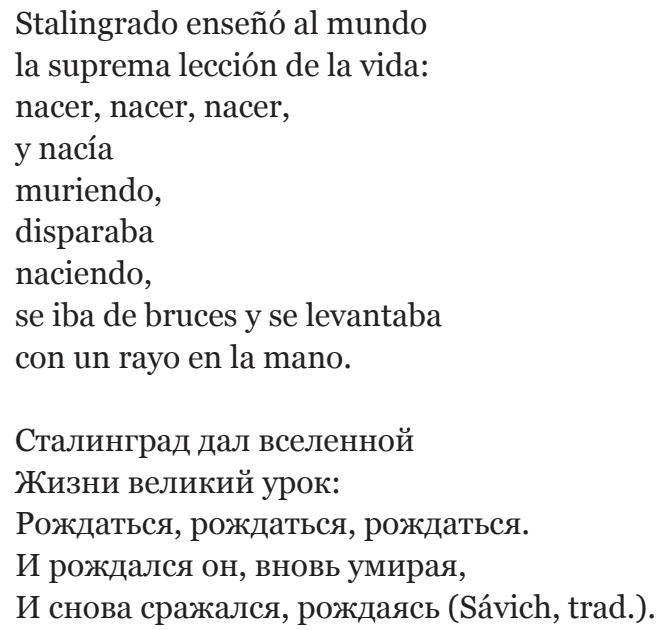

Las ocho traducciones representan interpretaciones poéticas de las obras maestras de Neruda sobre Stalingrado. Cada una provoca un sentimiento de orgullo por la heroica ciudad del Volga y la sensación de formar parte de un diálogo entre las culturas chilena, y más ampliamente, latinoamericana y rusa en las personas de un gran poeta chileno y las seis brillantes personalidades de los literatos rusos, cuyo trabajo inspirado e innovador en las traducciones de los poemas de Neruda a Stalingrado hicieron posible la transmisión y custodia del mensaje poético y cívico del poeta chileno, un mensaje que todavía reverbera en el setenta aniversario de la Gran Victoria. De esta manera se cumple el deseo del poeta mismo (1967e: 1237):

Con la luz de otras vidas

vivirán otras vidas en mi canto. 


\section{Referencias}

Ehrenburg, I. G. (1949). Introducción. En P. Neruda, Stiji (pp. 5-18) Moscú: Izdatelstvo Inostranoi Literatuti.

. (1965). Sobranie sochineniy v 9 tomaj. Vol. 6. Moscú: Judozhestvennaia Literatura.

Ercilla y Zúñiga, A. (1776). La Araucana, Primera, Segunda y Tercera Parte. Disponible en https://books.google.com/books?id=woRX-qrpqKQC\&prin tsec $=$ frontcover $\& \mathrm{dq}=\mathrm{la}+$ araucana + parte $+1 \& \mathrm{hl}=\mathrm{en} \& \mathrm{sa}=\mathrm{X} \& \mathrm{ved}=\mathrm{oCB} 4 \mathrm{Q} 6 \mathrm{~A}$ EwAGoVChMIldKpgumzxwIVw6ceChooIAJ4\#v=onepage\&q=la\%20araucana\%2oparte\%201\&f=false.

Goncharenko, S. F. (2014). K voprosu o poeticheskom perevode. Mosti. Zhurnal Perevodchikov, 4 (44), 6-13.

Neruda, P. (1943). Nuevo canto de amor a Stalingrado. México: Comité de Ayuda a Rusia en Guerra.

. (1950). Canto de amor a Stalingrado (F. Kellin, trad.). Biblioteca "Ogoniok", 23, 21-24.

. (1950a). Nuevo canto de amor a Stalingrado. (F. Kellin, trad.). Biblioteca "Ogoniok", 23, 25-27.

. (1965). Obyasnenie. En I. Ehrenbug, Sobranie sochineniy v 9 tomaj. (I. Ehrenburg, trad.). Vol. 6 (pp. 634-635). Moscú: Judozhestvennaia Literatura.

. (1967). Canto a Stalingrado. En P. Neruda, Obras completas. Vol. 1 (pp. 296-298). Tercera edición. Buenos Aires: Losada.

. (1967a). Nuevo canto de amor a Stalingrado. En P. Neruda, Obras completas. Vol. 1 (pp. 298-304). Tercera edición. Buenos Aires: Losada.

. (1967b). Tercer canto de amor a Stalingrado. En P. Neruda, Obras completas. Vol. 1 (pp. 801-804). Tercera edición. Buenos Aires: Losada.

. (1967c). Erenburg. En P. Neruda, Obras completas. Vol. 1 (pp. 737-739).

Tercera edición. Buenos Aires: Losada.

. (1967d). Explico algunas cosas. En P. Neruda, Obras completas. Vol. 1

(pp. 275-277). Tercera edición. Buenos Aires: Losada.

. (1967e). Oda a la crítica (II). En P. Neruda, Obras completas. Vol. 1 (p. 1237). Tercera edición. Buenos Aires: Losada.

- (1976). Ia pishu dlia naroda. En P. Neruda, Ia vizhu chto griadiot y chto narozhdaietsa. Izbrannoe (S. Goncharenko, trad.) (pp. 363-368). Moscú: Progreso.

. (1982). Canto de amor a Stalingrado (P. Grushkó, trad.). En P. Neruda, Vriemia zhizni (pp. 44-46). Moscú: Molodaia Gvardia. . (1982a). Nuevo canto de amor a Stalingrado (S. Goncharenko, trad.). En

P. Neruda, Vriemia zhizni (pp. 46-49). Moscú: Molodaia Gvardia. . (1984). Nuevo canto de amor a Stalingrado (E. Dolmatovsky, trad.). En 
V. Slavi, Antologia judozhestvennij proizvedenii o Velikoi Otechestevennoi voine v 12 tomaj. Vol. 4 (pp. 577-580). Moscú: Sovremennik.

. (2005). Tercer canto de amor a Stalingrado (Ovadiy G. Sávich, trad.). En P. Neruda, 60 Aniversario de la Victoria (pp. 63-65). Moscú: Embajada de Chile en la Federación Rusa.

The Official Web Site of the Nobel Prize. (agosto de 2015) Nobel Prizes and Laureates. Disponible en http://www.nobelprize.org/nobel_prizes/.

Vassílieva-Shvede, O. K. (1948). Kurs ispanskogo yzsika. Dlia visshij uchebnij zavedenii. Moscú: Izdatelstvo Literaturi na Inostrannij Yazikaj. 